the Institution of Gas Engineers); and Prof. A. L. Roberts (Livesey professor of coal gas and fuel industries in the University of Leeds). The laboratories of the North Thames Gas Board have been recognized as the nucleus of a London research station, and Dr. H. Hollings, who for some years has been controller of those laboratories, has joined the committee as director-designate of the station.

\section{University of Glasgow: Fifth Centenary}

THe University of Glasgow will celebrate its fifth centenary during June 1951. Representatives of universities, learned societies and public bodies and persons distinguished in academic and public life are being invited. The main ceremonial functions will be during June 19-21, culminating in a visit by the King and Queen on the last day. The meetings will include the presentation of addresses by delegates in the Bute Hall of the University, a commemoration service in the Cathedral, and meetings in St. Andrews Hall, including an honorary graduation. The Fifth Centenary Medal in bronze, $2 \frac{1}{2} \mathrm{in}$. diameter, is now being struck. Publications will include an illustrated brochure upon historical and contemporary aspects of the University; a volume of Fifth Centenary Lectures which will be delivered during the 1950-51 academic session; a history of the University ; and "The Book of The Fifth Centenary", which will be the official record of the occasion. The arrangements are in the hands of the University of Glasgow Fifth Centenary Committee, Glasgow, W.2, the secretary of which is Mr. J. B. Neilson.

\section{Fourth Congress of the International Scientific Film Association}

THE fourth Congress of the International Scientific Film Association will be held in Florence during October 14-22. As in the case of the three previous Congresses held in Paris, London and Brussels, there will be a festival of scientific films, as well as specialist group meetings of the Medical, Research Film and Industrial Film Committees, and also the business meetings of the general assembly of the Congress. A special committee of the British Scientific Film Association has been formed to recommend films for submission to the festival, and prospective exhibitors should, as soon as possible, send to the Association full details about their films, including running-time, gauge, date of production, brief synopsis, ete. The address of the British Scientific Film Association is 4 Great Russell Street, London, W.C.1.

\section{U.S. National Academy of Sciences: Autumn Meeting}

THe autumn meeting of the U.S. National Academy of Sciences will be held at the Research Laboratory, General Electric Co., Schenectady, New York, during October 9-12. On the afternoon of October 9 the new buildings of the Research Laboratory will be dedicated, and C. E. Wilson, president of the General Electric Co., will be the principal speaker. On the evening of October 10 Dr. C. P. Rhoads, director of the Sloan-Kettering Institute for Cancer Research, will deliver a public lecture in the Memorial Chapel, Union College. The Academy dinner for members, guests and members of the Capitol District Sections of Technical Societies will be held on October 11, and Sir Lawrence Bragg, Cavendish professor of experimental physics in the University of Cambridge, will be the principal speaker.

\section{Announcements}

A memoriat window to the late Sir Charles Parsons will be unveiled in Westminster Abbey on October 5 by Sir Robert Robinson, president of the Royal Society. The window will be dedicated by the Dean of Westminster, and a memorial oration will be delivered by Sir Frank Smith.

THE Couneil of the British Coal Utilisation Research Association has appointed Mr. R. L. Brown to succeed the late Dr. D. H. Bangham as director of research laboratories. Mr. Brown joined the staff of the Association in 1938, having earlier taken first-class honours in the Mathematical Tripos at Cambridge.

Mr. J. S. Sheppard has been appointed to the University readership in mine surveying tenable at the Imperial College of Science and Technology, London.

THE Edward Teshmaker Busk studentship of $£ 300$ a year for research in experimental and mathematical aeronautics carried out in Great Britain or abroad has been awarded for the year $1950-51$ to Robert Westley, of the College of Aeronautics, Cranfield.

THE Institute of Biology, which held its first general meeting in King's College, London, on January 5 (see Nature, 165, 131; 1950), has now obtained office premises at $17 a$ Onslow Gardens, London, S.W.7, telephone number Kensington 4882-3. Mr. A. Fielding Clarke has been appointed general secretary. All communications should be addressed to the general seeretary, who will be glad to supply further information to prospective members.

The Physical Society will hold a symposium on cosmic rays on September 29, and on November 24 a number of papers will be given on various aspects of electrical discharge. On December 8 the autumn provincial meeting of the Society will be held at Cambridge, when Sir James Chadwick will deliver the Rutherford Lecture. Further details of these meetings can be obtained from the Secretary, Physical Society, I Lowther Gardens, Prince Consort Road, London, S.W.7.

THE twenty-first annual conference of the National Smoke Abatement Society will be held at Margate during September 27-29. The Conference will be marked by the presentation of the first Des Voeux Memorial Lecture, established in honour of the Society's first president, Dr. H. A. Des Voeux, who helped to found one of its two parent bodies in London in 1899. It will be delivered by Dr. D. T. A. Townend, director-general of the British Coal Utilisation Research Association. Further particulars of the Conference can be obtained from the general secretary of the Association, Chandos House, Buckingham Gate, London, S.W.1.

THE twelfth National Conference for the Preservation of the Countryside, organised by the Council for the Preservation of Rural England, will be held at Tunbridge Wells during October 19-22. The theme this year will be "Modern Developments in Rural England", and three sessions on, respectively, the impact of industry on rural life, problems of rural electrification, and planning and afforestation, will be held in the Assembly Hall, Tunbridge Wells. The headquarters of the Conference will be at the Spa Hotel, where there will be an inquiry office. Further details can be obtained from the Secretary, C.P.R.E., 4 Hobart Place, London, S.W.1. 